\title{
Proliferation, Multiplication and Improvement of Micro-Propagation System for Mass Clonal Production of Rose through Shoot Tip Culture
}

\author{
Allah Jurio Khaskheli', Muhammad Ibrahim Khaskheli' ${ }^{2}$, Maqsood Ahmad Khaskheli ${ }^{3}$, \\ Tahmina Shar ${ }^{3}$, Waqas Ahmad ${ }^{4}$, Umed Ali Lighari' ${ }^{3}$, Muhammad Azeem Khaskheli5, \\ Asad Ali Khaskheli', Faisal Hayat Makan4
}

${ }^{1}$ Department of Biotechnology, Sindh Agriculture University, Tando Jam, Pakistan

${ }^{2}$ Department of Plant Protection, Sindh Agriculture University, Tando Jam, Pakistan

${ }^{3}$ State Key Laboratory of Rice Biology, China National Rice Research Institute, Hangzhou, China

${ }^{4}$ Collage of Agriculture and Biotechnology, China Agriculture University, Beijing, China

${ }^{5}$ Institute of Pomology, Chinese Academy of Agriculture Sciences, Xingcheng, China

${ }^{6}$ Department of Animal Nutrition, Sindh Agriculture University, Tando Jam, Pakistan

Email: aajkhaskheli@gmail.com

How to cite this paper: Khaskheli, A.J., Khaskheli, M.I., Khaskheli, M.A., Shar, T., Ahmad, W., Lighari, U.A., Khaskheli, M.A., Khaskheli, A.A. and Makan, F.H. (2018) Proliferation, Multiplication and Improvement of Micro-Propagation System for Mass Clonal Production of Rose through Shoot Tip Culture. American Journal of Plant Sciences, 9, 296-310.

https://doi.org/10.4236/ajps.2018.92024

Received: December 29, 2017

Accepted: January 28, 2018

Published: January 31, 2018

Copyright (c) 2018 by authors and Scientific Research Publishing Inc. This work is licensed under the Creative Commons Attribution International License (CC BY 4.0).

http://creativecommons.org/licenses/by/4.0/ (c) (i) Open Access

\begin{abstract}
Present study was conducted to assess the regeneration potential and producing mass-clonal seedlings of Rose through shoot tip culture. A total of $40 \mathrm{ex}-$ plants were cultured on each of basal medium supplemented with different concentrations of BAP, NAA and GA. The observations on the survival rate, days taken to initiate the shoots, total number of shoots and length of shoots, initiation of roots, total number of root, length of roots and number of leaves were investigated. Rose regenerated on MS-Basal medium (control) without addition of growth hormones showed significantly $(\mathrm{P}<0.05)$ lower survival rate and did not show shoots up to the end of experiments. MS-Basal medium supplemented with different concentrations of BAP, NAA and GA showed increasing rate of survival. MS-Basal medium supplemented with highest BAP, NAA and GA concentration (MS-SV) has taken least time to initiate the shoots, whilst supplemented in concentrations of 0.5 and/or $1.0 \mathrm{mg} / \mathrm{L}$, respectively revealed more time. Rooted plants were transplanted into the substrate and acclimatized in the laboratory greenhouse (humid cavity). The acclimatization in the humid cavity showed optimistic effect on the number of survived plants.
\end{abstract}

\section{Keywords}

Rose, Tissue Culture, Explants, BAP, NAA and GA 


\section{Introduction}

Rose (Rosa hybrid L.) is one of the most important and economic ornamental plants worldwide [1]. The cut roses are one of the most famous and popular amongst all cut flowers in global floriculture trade. Further, rose is commonly known as the "King of Flowers" as well as "Queen of Flowers" due to its inherent qualities such as kingliness. Additionally, in vitro multiplication of rose is very useful because it provides a means of overcoming difficulties of producing large numbers of relatively homogenous seedlings and system was extensively used in wide range of tissue culture investigations carried-out by many scientists. The findings of these techniques provided an argument for the use of tissue and cell culture techniques as tools for rose improvement [2].

Tissue culture micropropagtion has been employed to aid in the clonal propagation of numerous plant species. The inherent advantage of tissue culture over field propagation is the greater plant production potential from a single plant. Tissue culture techniques may offer a possible method to produce large numbers of genetically uniform seedlings. Several reports dealing with tissue culture in rose have appeared in the literature [3]. Production of a sexual embryos and their subsequent development into free-living plants was the first published report in the literature has obtained free-living plants from clonal propagated explants tissues derived from shoot tips, lateral buds and inflorescence. At a later date, similar studies were also begun in various Institutes of the world [4].

Nowadays, tissue culture or micro propagation which is frequently used in the every Research Institutes of the Pakistan; and also Research Institutes of the world. It is generally accepted that term plant tissue culture broadly refers to in vitro cultivation of all plant parts, tissues, meristem tips, buds, shoots, stem, flowers and embryo etc. Plant tissue culture is a technique, which has great potential as a means of vegetative propagating economically important species; a potential, which is being realized commonly at present. Micropropagation involves the production of plants from very small plant parts, tissues or cells grown especially in a test tube or other container where the environment and nutrition can be rigidly controlled. This technique is now often preferred to congenital practices of asexually propagation in several green house species because, only a small amount of plant tissues are needed as the initial explants for regeneration of millions of colonel parts [5] [6] [7] [8].

As discussed above that, tissue culture technologies are now extensively used as a biological tool for clonal propagation, disease elimination and mass propagation of several agricultural crops. Thus, keeping in mind the above facts and potentiality of tissue culture technology, the present study has been planned to evaluate the proliferation rate, multiplication and thus present study was also focused on to improvement of micro-propagation system for mass-clonal production of rose through shoot tip culture. 


\section{Materials and Methods}

\subsection{Plant Materials}

The excised materials (explants) were collected from the greens houses and nursery field and for further processing the explants were then brought into the Tissue Culture Laboratory, Department of Biotechnology, Sindh Agriculture University, Tando jam during 2017.

\subsection{Preparation of Micronutrient Stock Solution}

The quantities each of salts (Table 1) were measured accordingly and transferred into conical flask. Sterilized distilled water $(700 \mathrm{ml})$ was delivered into conical flask and stirred to dissolve properly on magnetic stirrer. Solution was transferred to volumetric flask ( $1 \mathrm{~L})$ and made up to volume. The flask was labeled and stored in refrigerator.

\subsection{Preparation of Vitamin-Based Stock Solution}

The quantities of ingredients for vitamin stock (Table 1) were measured into conical flask having some quantity of sterilized distilled water and mixed thoroughly using magnetic stirrer. The solution was transferred into volumetric flask $(1 \mathrm{~L})$ and made up to volume. The flask was labeled and stored in refrigerator till use.

\subsection{Preparation of Iron Stock Solution}

The quantities each of ingredients for iron stock solution were measured into conical flask and an appropriate quantity of sterilized distilled water was added.

Table 1. Composition of MS basal media.

\begin{tabular}{|c|c|c|}
\hline Sr. No. & Ingredients & Quantity used (g/L) \\
\hline I. & \multicolumn{2}{|c|}{ Micronutrient Stock Solution } \\
\hline & Manganese sulphate $\left(\mathrm{MnSO}_{4} \cdot 4 \mathrm{H}_{2} \mathrm{O}\right)$ & 16.9 \\
\hline & Zinc sulphate $\left(\mathrm{ZnSO}_{4} \cdot 7 \mathrm{H}_{2} \mathrm{O}\right)$ & 8.6 \\
\hline & Boric acid $\left(\mathrm{H}_{3} \cdot \mathrm{BO}_{3}\right)$ & 6.2 \\
\hline & Potassium iodide (KI) & 0.83 \\
\hline & Sodium molybdate $\left(\mathrm{Na} \mathrm{MoO}_{4} \cdot 2 \mathrm{H}_{2} \mathrm{O}\right)$ & 0.025 \\
\hline & Copper sulphate $\left(\mathrm{CuSO}_{4} \cdot 5 \mathrm{H}_{2} \mathrm{O}\right)$ & 0.025 \\
\hline & Cobalt chloride $\left(\mathrm{CoCl}_{2} \cdot 6 \mathrm{H}_{2} \mathrm{O}\right)$ & 0.025 \\
\hline \multirow[t]{6}{*}{ II. } & \multicolumn{2}{|c|}{ Vitamin-based Stock Solution } \\
\hline & Pyridixone $\mathrm{HCL}\left(\mathrm{C}_{8} \mathrm{H}_{12} \mathrm{ClNO}_{3}\right)$ & 0.5 \\
\hline & Thiamine HCL $\left(\mathrm{C}_{12} \mathrm{H}_{8} \mathrm{~N}_{4} \mathrm{OSCl}_{2}\right)$ & 0.5 \\
\hline & Nicotinic acid $\left(\mathrm{C}_{6} \mathrm{H}_{5} \mathrm{NO}_{2}\right)$ & 0.1 \\
\hline & Glycine $\left(\mathrm{NH}_{2} \mathrm{CH}_{2} \mathrm{COOH}\right)$ & 2.0 \\
\hline & Casein acid & 2.0 \\
\hline \multirow[t]{3}{*}{ III. } & \multicolumn{2}{|c|}{ Iron Stock Solution } \\
\hline & Iron sulphate $\left(\mathrm{FeSO}_{4} \cdot 7 \mathrm{H}_{2} \mathrm{O}\right)$ & 27.80 \\
\hline & Sodium EDTA $\left(\mathrm{Na}_{2}\right.$ EDTA $\left.2 \mathrm{H}_{2} \mathrm{O}\right)$ & 37.26 \\
\hline
\end{tabular}

Murashige and Skooge, 1962. 
The solution was mixed on magnetic stirrer and transferred into volumetric flask $(1 \mathrm{~L})$. Finally the sterilized distilled water was added up to mark and stored in refrigerator till use.

\subsection{Preparation of MS-Basal Medium}

The recommended quantities of macronutrient, sucrose $(30 \mathrm{~g})$, activated charcoal $(0.3 \mathrm{~g})$ and agar $(7-8 \mathrm{~g})$ were measured into conical flask and to which sterilized distilled water $(800 \mathrm{ml})$ was added and each of stock solution $(1 \mathrm{ml})$ were added. Solution was stirred and remaining sterilized distilled water was added to final volume of solution $(1 \mathrm{~L})$. $\mathrm{pH}$ of media was adjusted (5.7) using $1 \mathrm{~N} \mathrm{NaOH}$ solution and microwaved ( $4 \mathrm{~min}$.) till become transparent. Media was poured into bottled $(100 \mathrm{ml})$ and after plugging, it was autoclaved $\left(121^{\circ} \mathrm{C}\right)$ at $15 \mathrm{psi}$ for $20 \mathrm{~min}$. and stored in refrigerator till use.

\subsection{Preparation of Growth Regulators Stock Solution}

$0.1 \mathrm{~g}$ of each growth regulators i.e. BAP, NAA and GA were measured into beaker and dissolved by adding drops of $\mathrm{NaOH}(1 \mathrm{~N})$. Some quantity of sterilized distilled water was added to beaker and mixed with magnetic stirrer. The solution was transferred to $100 \mathrm{ml}$ volumetric flask and made up volume up to mark with sterilized distilled water. It was then stored at $0^{\circ} \mathrm{C}$ till further use.

\subsection{Preparation of Shoot Culture Media}

The ingredients of MS-Basal medium were measured into each of five conical flasks and sterilized distilled water $(800 \mathrm{ml})$ was added to them. Each of these supplemented with stock solutions with concentration of BAP, NAA and GA (Table 2 ) respectively. Solution was stirred on magnetic stirrer and remaining sterilized distilled water was added to final volume of 1 liter. $\mathrm{pH}$ of media was adjusted (5.7) using $1 \mathrm{~N}$ HCL solution and boiled to transparent liquid using microwave oven. Media was transferred into bottles $(100 \mathrm{ml})$ and plugged properly. These were then autoclaved $\left(121^{\circ} \mathrm{C}\right)$ at $15 \mathrm{psi}$ for $20 \mathrm{~min}$. and stored in refrigerator.

\subsection{Surface Sterilization}

Explants were thoroughly cleaned removed to expose the shoot tip and lateral

Table 2. Shoots induction media.

\begin{tabular}{cc}
\hline Media & Concentrations \\
MS-SI & MS-Basal + 0 mg/L BAP + 0 mg/LNAA + 0 mg/L GA \\
MS-SII & MS-Basal + 0.5 mg/L BAP + 0.1 mg/LNAA + 0.5 mg/L GA \\
MS-SIII & MS-Basal + $1 \mathrm{mg} / \mathrm{L} \mathrm{BAP} \mathrm{+} \mathrm{0.5mg/LNAA} \mathrm{+} \mathrm{0.5} \mathrm{mg/L} \mathrm{GA}$ \\
MS-SIV & MS-Basal + $2 \mathrm{mg} / \mathrm{L} \mathrm{BAP}+0.75 \mathrm{mg} / \mathrm{LNAA}+0.5 \mathrm{mg} / \mathrm{L} \mathrm{GA}$ \\
MS-SV & MS-Basal + $3 \mathrm{mg} / \mathrm{L} \mathrm{BAP} \mathrm{+} 1 \mathrm{mg} / \mathrm{LNAA}+0.5 \mathrm{mg} / \mathrm{L} \mathrm{GA}$ \\
MS-SVI & MS-Basal + $4 \mathrm{mg} / \mathrm{L} \mathrm{BAP}+1.2 \mathrm{mg} / \mathrm{LNAA}+0.5 \mathrm{mg} / \mathrm{L} \mathrm{GA}$ \\
\hline
\end{tabular}


buds region. The exposed region was excised and immediately placed in antioxidant solution. The shoot tip and lateral buds were surface sterilized in $70 \%$ ethanol for $15 \mathrm{~min}$., and the soaking in $100 \%$ Sodium hypochlorite (domestic bleach) solution containing 2 - 3 drops of Tween-20 for $30 \mathrm{~min}$. followed by rinsing three times with sterilized distilled water. Further, manipulation of the explants was occurred in a laminar air flow cabinet with flamed instruments.

\subsection{Preparation of Laminar Air Flow Cabinet}

Laminar air flow cabinet was started before $30 \mathrm{~min}$. of culturing. It was swapped with $70 \%$ ethanol and then sterilized with ultra violet (UV) rays for $15 \mathrm{~min}$. All the instruments like Knives, scissors, forceps, scalpels, medium bottles, Petri dishes, spirit lamp, and glass plate etc. were kept under sterilized conditions in the laminar air flow cabinet.

\subsection{Experimental Design}

Culturing of rose was performed according the shoot tip culture technique as reported by Shah et al. [4] with slight modifications. Briefly the explants were cultured on Murashige and Skooge [9] Basal medium. A total of 40 explants were cultured on each of Basal medium supplemented with concentrations of BAP, NAA and GA (Table 2). The observations on the survival rate, days taken to initiate the shoots, total number of shoots and length of shoots were recorded. Further, the regenerated shoots were dissected and transferred to rooting media MS-Basal + NAA with various concentrations (Table 3). The observations on days taken to initiate the roots, total number of roots and length of roots were noted. Experiment was replicated in triplicate.

\subsection{Statistical Analysis}

The obtained data were statistically analyzed accordingly to analysis of variance

Table 3. Root induction media.

\begin{tabular}{cc}
\hline Media & Concentrations \\
\hline MS-RI & MS-Basal + $0 \mathrm{mg} / \mathrm{L}$ IAA \\
MS-RII & MS-Basal + 0.5 mg/L IAA \\
MS-RII & MS-Basal + $1 \mathrm{mg} / \mathrm{L}$ IAA \\
MS-RIV & MS-Basal $+2 \mathrm{mg} / \mathrm{L}$ IAA \\
MS-RV & MS-Basal $+3 \mathrm{mg} / \mathrm{L}$ IAA \\
MS-RVI & MS-Basal $+4 \mathrm{mg} / \mathrm{L}$ IAA \\
\hline
\end{tabular}

Note: Shoot Induction media: MS-SI = Murashige and Skooge-Shoot Induction media-I; MS-SII = Murashige and Skooge-Shoot Induction media-II; MS-SIII = Murashige and Skooge-Shoot Induction media-III; MS-SIV = Murashige and Skooge-Shoot Induction media-IV; MS-SV = Murashige and Skooge-Shoot Induction media-V; MS-SVI = Murashige and Skooge-Shoot Induction media-VI. Root Induction media: MS-SI = Murashige and Skooge-Root Induction media-I; MS-SII = Murashige and Skooge-Root Induction media-II; MS-SIII = Murashige and Skooge-Root Induction media-III; MS-SIV = Murashige and Skooge-Root Induction media-IV; MS-SV = Murashige and Skooge-Root Induction media-V; MS-SVI = Murashige and Skooge-Root Induction media-VI. 
(ANOVA). The treatment means were compared using Least Significant Difference (LSD) at 5\% level of Probability. All computational and statistical analysis were performed using student edition software package 8.1.

\section{Results}

\subsection{In Vitro Regeneration and Proliferation of Shoots through Shoot Tip Culture}

The results for proliferation of rose regenerated on MS medium supplemented with different concentrations of BAP, NAA and Kinetin are presented in Figures (a)-(d). It was observed that rose explants cultured on MS medium without addition of hormones (MS-SI) showed significantly $(\mathrm{P}<0.05)$ lower survival rate (72.50\%) compared to explants on MS medium supplemented with various concentrations of BAP, NAA and GA. Result further reveals that survival rate of explants cultured on MS media supplemented with either MS-SII or MS-SIII each of BAP, NAA and GA was relatively similar $(\mathrm{P}>0.05)$ and were significantly $(\mathrm{P}$

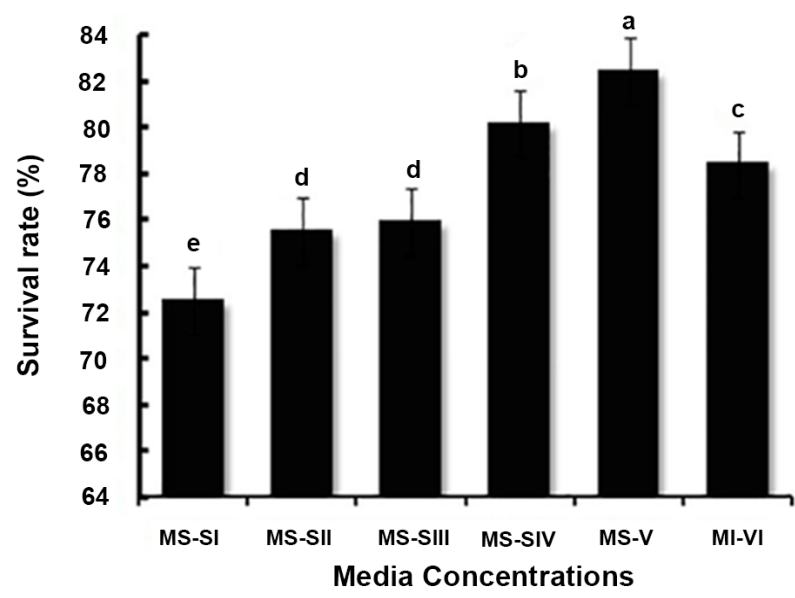

(a)

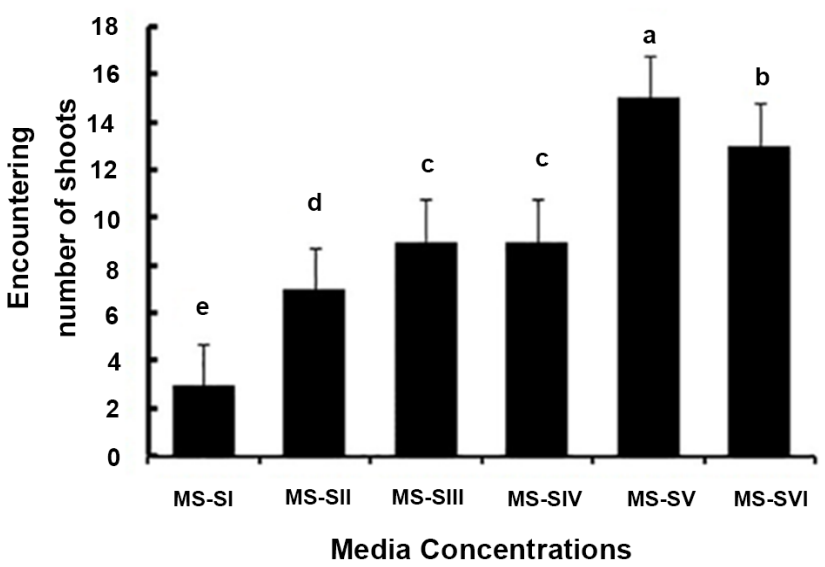

(c)

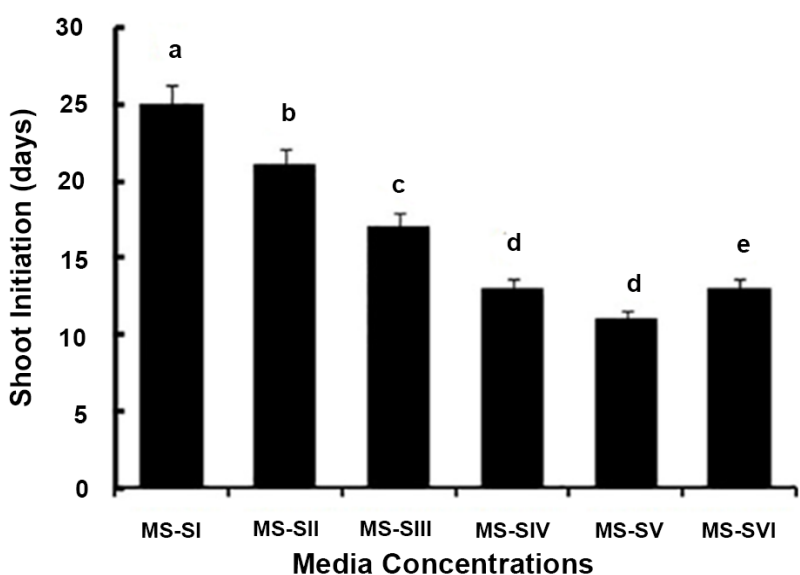

(b)

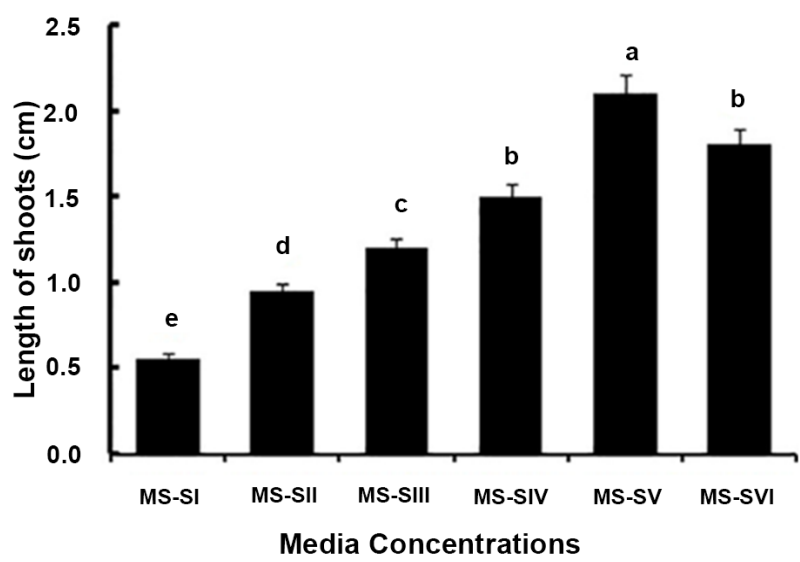

(d)

Figure 1. In vitro regeneration of shoots of rose through shoot tip culture. Survival rate (a), shoot initiation (b), encountering the number of shoots (d), Length of shoots (d). ${ }^{\mathrm{a}, \mathrm{b}}$ means followed by different letter (s) in different columns denotes statistical significant difference regarding analysis of variance. The treatment means were compared using Least Significant Difference (LSD) at 5\% level of Probability. Data are the average of three different biological replications. 
$<0.05)$ optimized $(75.5 \pm 1.18$ or $75.89 \% \pm 0.10 \%$, respectively) than that of cultured on MS medium supplemented with lower concentrations of BAP, NAA and GA(i.e. MS-SI). It is of a interest to note that there were no any significant differences $(\mathrm{P}>0.05)$ found to be amongst the survival rate of rose explants cultured on MS medium supplemented with concentrations of $0.5 \mathrm{mg} / \mathrm{L}, 1.0 \mathrm{mg} / \mathrm{L}$ or $2.0 \mathrm{mg} / \mathrm{L}$ each of BAP, NAA and GA i.e. $75.50 \pm 0.28,75.47 \pm 0.18$ and $75.33 \% \pm 0.8 \%$, respectively. Furthermore, compare to that of other medium concentrations, the MS-V medium showed remarkably better response and showed significantly higher survival rate (82.4 \pm 1.08$)$ (Figure 2$)$.

\subsection{Growth Hormonal Efficiency Effect the Shoot Initiation}

It was further observed that the explants cultured on MS-SI medium has taken more time $(25.0 \pm 0.21$ days) to initiate the shoot (Figure $1(\mathrm{~b}))$. While, on MS-SV medium has taken least time (11.0 \pm 0.15 days). It was further noted that the explants of rose cultured on MS-SII and MS-SIII media have taken downward curve timely response (i.e. $21.28 \pm 0.12$ and $17.45 \pm 0.19$ days). However,
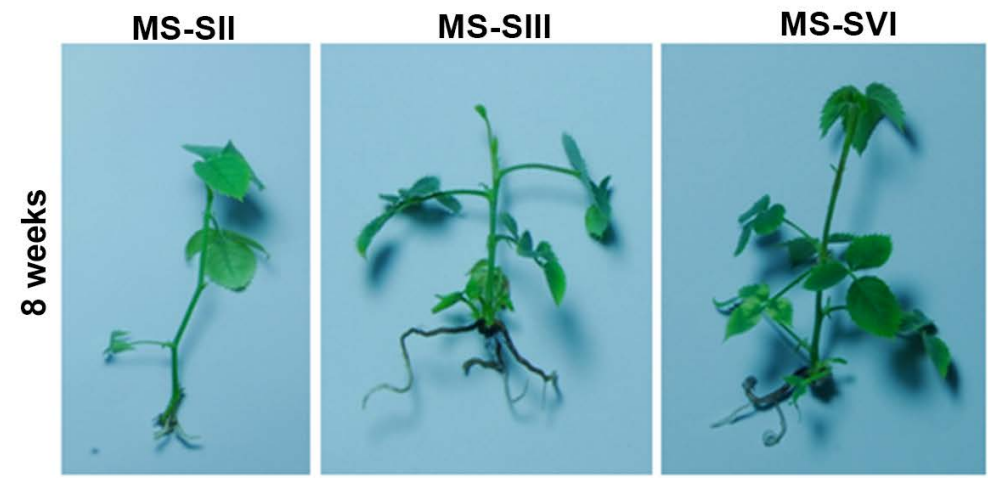

(a)

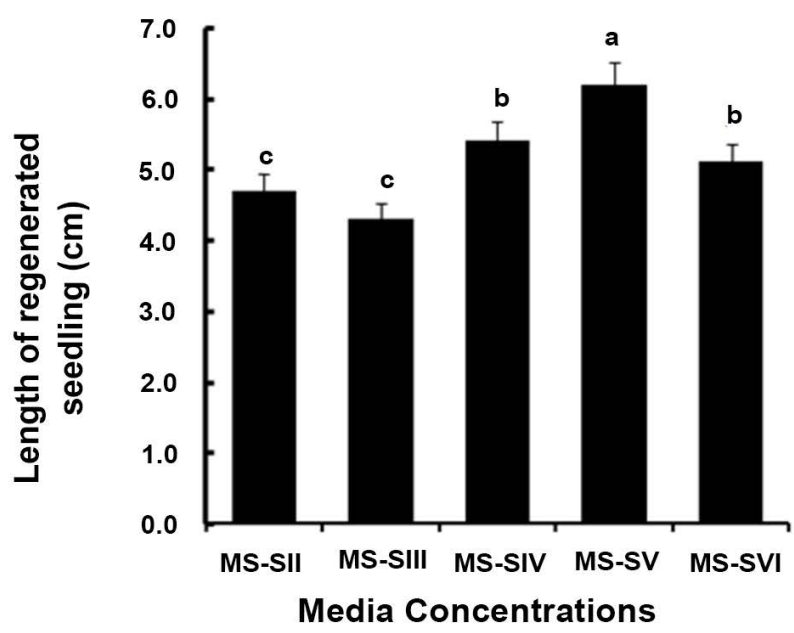

(b)

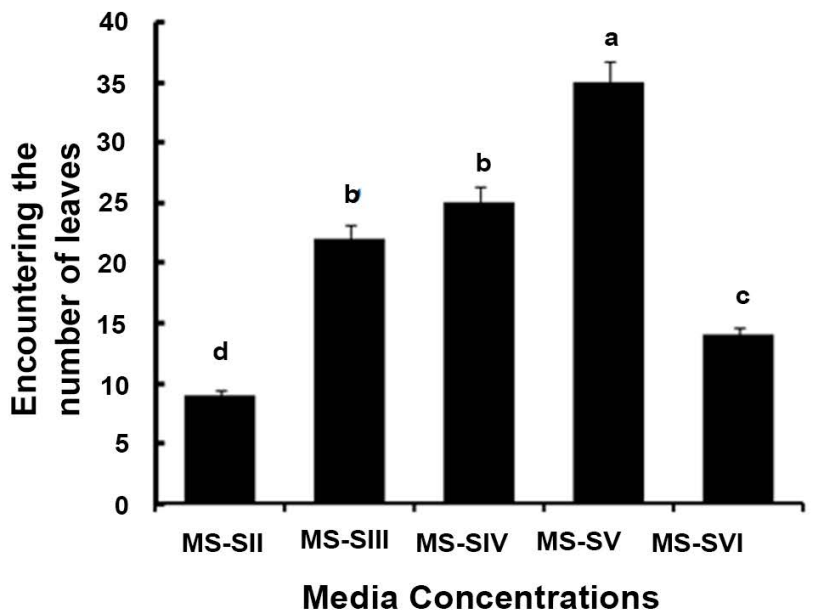

(c)

Figure 2. Regulation of in vitro regenerated seedlings of rose. Phenotypic observation of regenerated seedlings (a), length of regenerated seedlings (b), encountering the number of leaves (c). ${ }^{a, b}$ means followed by different letter(s) in different columns denotesstatistical significant difference regarding analysis of variance. The treatment means were compared using Least Significant Difference (LSD) at 5\% level of Probability. Data are the average of three different biological replications. 

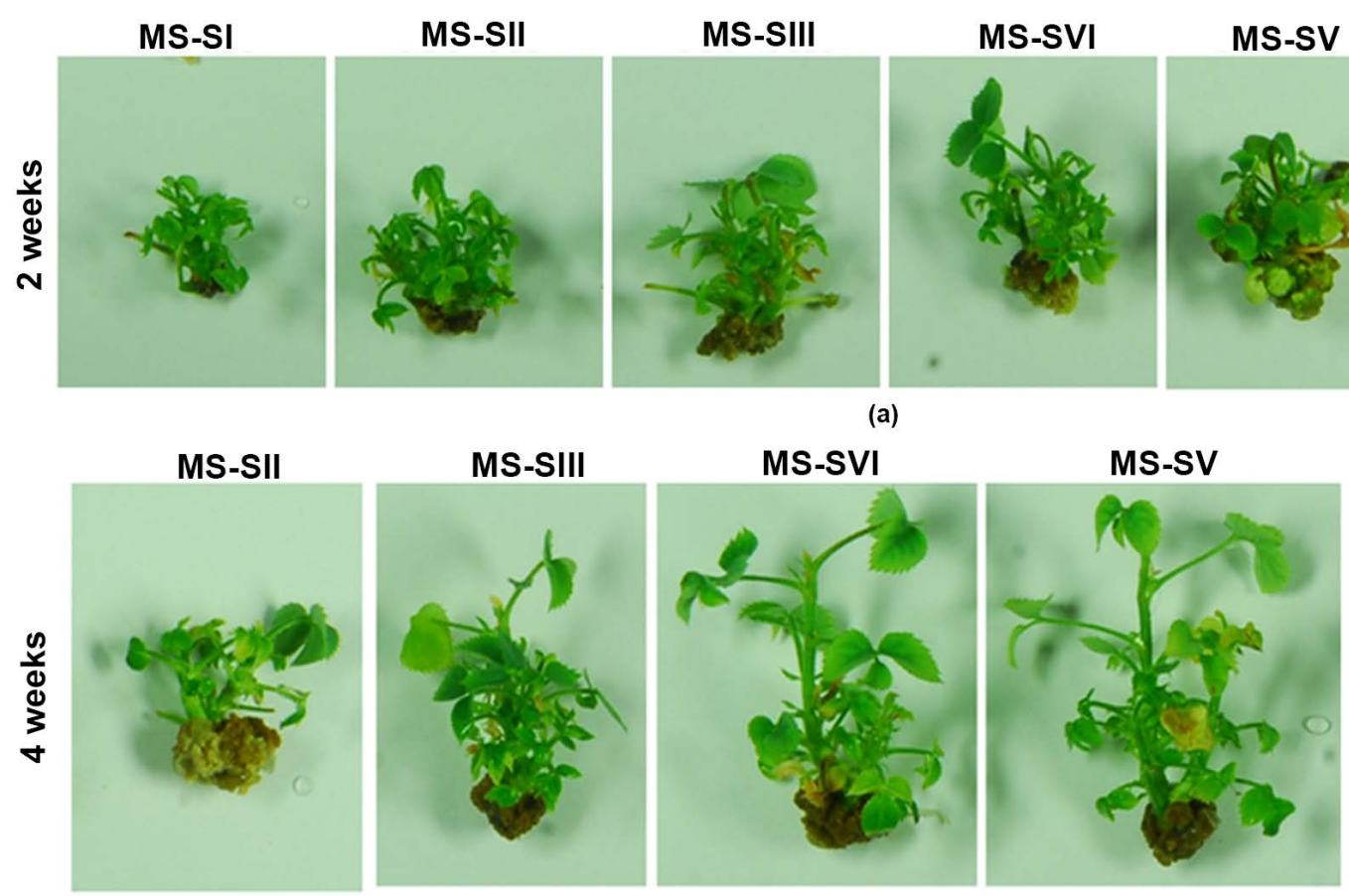

(b)
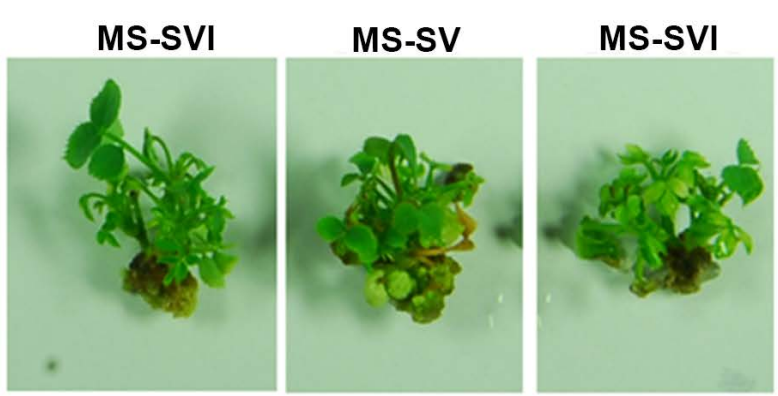

MS-SVI
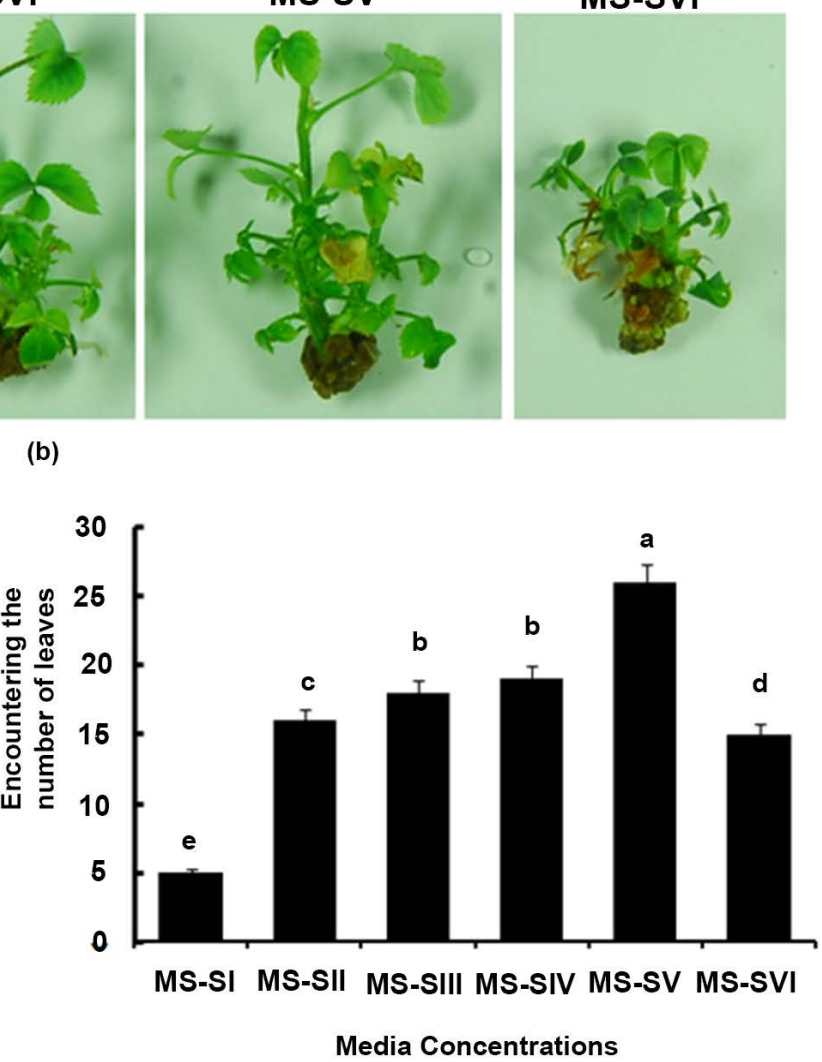

(d)

Figure 3. Growth hormonal efficiency affected the length and number of leaves. Phenotypic observation of seedlings obtained after weeks of regeneration (a), (b), Length of seedlings (c), Encountering the number of leaves (d) ${ }^{a, b}$ means followed by different letter (s) in different columns denotesstatistical significant difference regarding analysis of variance. The treatment means were compared using Least Significant Difference (LSD) at 5\% level of Probability. Data are the average of three different biological replications.

the explants cultured on these media have taken significantly less time as compared to MS-SI medium ( $25.50 \pm 0.21$ days). It was also found that there were no any significant differences $(\mathrm{P}>0.05)$ amongst replications of the explants cultured on different media (Figure 3 ).

\subsection{Number and Length of Shoots Influenced by Hormonal Concentrations}

In order to investigate the length of shoots and encountering the number of 
shoots, present study was focused to observe the efficiency medium concentrations on length and numbers of shoot. There was no any regenerated shoot of rose found on MS-Basal medium (control). However, MS-SII, MS-SIII and MS-SIV media showed more or less similar $(\mathrm{P}>0.05)$ number of shoots per explants i.e. $7.03 \pm 0.15,9.02 \pm 0.10$ and $9.02 \pm 0.10$, respectively (Figure $1(\mathrm{c})$ ). While, with increasing concentration of BAP, NAA and GA in MS-Basal medium substantially increased the number of shoots (i.e. $15.03 \pm 0.23$ and $13.03 \pm$ 0.26 , respectively) per explants. In the present study the highest numbers of shoot (15.03) were formed in MS-Basal medium supplemented with $4 \mathrm{mg} / \mathrm{L}$ BAP. Further in present study, $0.5 \mathrm{mg} / \mathrm{L}, 1.0 \mathrm{mg} / \mathrm{L}$ and $2.0 \mathrm{mg} / \mathrm{L}$ media showed relatively the similar $(\mathrm{P}<0.05)$ number of shoots per explants of rose, respectively. Results for the length of shoot of rose explants cultured on MS-Basal medium supplemented with different concentrations of BAP, NAA and GA are shown in Figure 1(d). It was observed that the shoot length was remarkably higher on MS-SV medium $(2.1 \pm 0.26 \mathrm{~cm})$ as compared to explants on other media i.e. MS-SII $(0.95 .42 \pm 0.17 \mathrm{~cm})$, MS-SIII $(1.2 \pm 0.14 \mathrm{~cm})$, MS-SIV $(1.5 \pm$ $0.18 \mathrm{~cm})$ and MS-SVI $(1.8 \pm 0.07 \mathrm{~cm})$ Figure $1(\mathrm{~d})$. It was further noted that regardless the rose explants cultured on MS-Basal medium (control) was not died, the shoot did not appear up to the end of experiment. Further, the significant variation in replications of the experiment was not found in the present study.

\subsection{Roots of Rose Exceedingly Pretentious by Oscillation of Hormonal Concentrations}

The results for days taken to initiate the roots from the shoot of rose regenerated on MS-basal medium supplemented with different concentrations of NAA was observed in present study. It was found that the shoots of rose regenerated on MS-RII and MS-RVI medium gave significantly little bit similar response and have taken more time (18.03 \pm 0.25 and $16.03 \pm 0.03$ days) to initiate the roots, whilst on MS-RV medium has taken least time (10.08 \pm 0.20 days). It was further noted that the roots of rose regenerated on MS-RIV medium (11.07 \pm 0.32$)$ have taken less time as compared to MS-RIII medium (15.20 \pm 0.19 days). However, MS-Basal medium (control) did not show any growth. It was also found that there were no any significant differences $(\mathrm{P}>0.05)$ amongst replications of the roots regenerated on different media. Furth, it was interestingly to note that, there was no any root of rose shoot grew on MS-Basal medium (control). However, MS-RII and MS-RIV media showed relatively similar $(P>0.05)$ number of roots per shoot of rose i.e. $3.05 \pm 0.09$ and $3.02 \pm 0.09$, respectively. It was further noted that MS-RIII and MS-RIV media also showed more or less similar response $(\mathrm{P}>0.05)$ i.e. $6.03 \pm 0.76$ and $6.05 \pm 0.12$ number of roots. Although these media showed significantly optimum number of roots compared to that of rose roots regenerated on MS-RIII and MS-RVI media. Whereas, rose shoots cultured on MS-RV medium exposed the significantly $(\mathrm{P}<0.05)$ highest number of roots amongst the other media. The results for the length of roots from the 

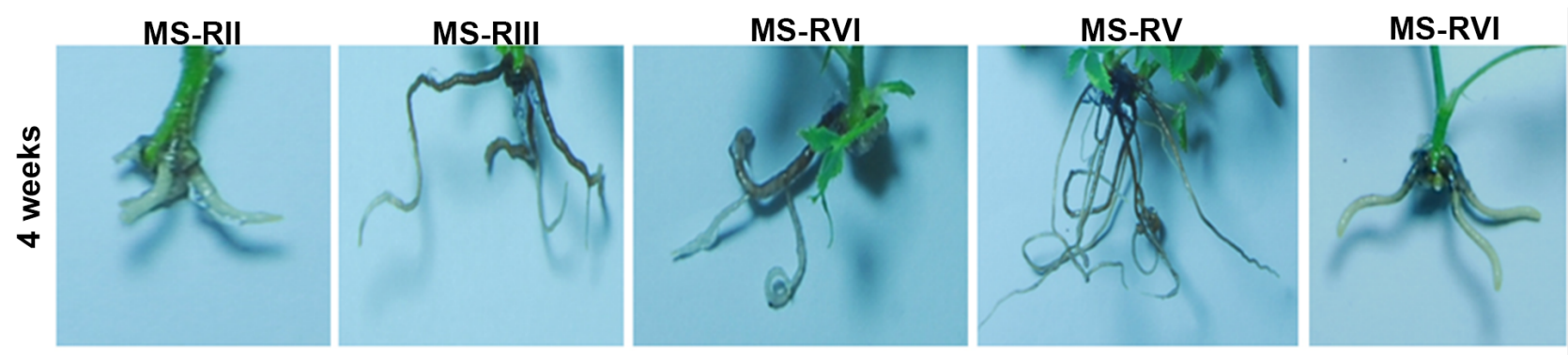

(a)

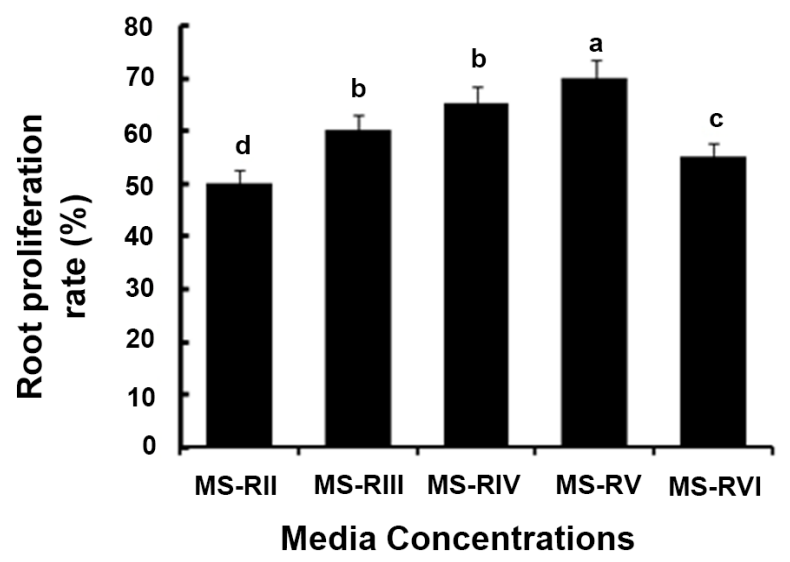

(b)

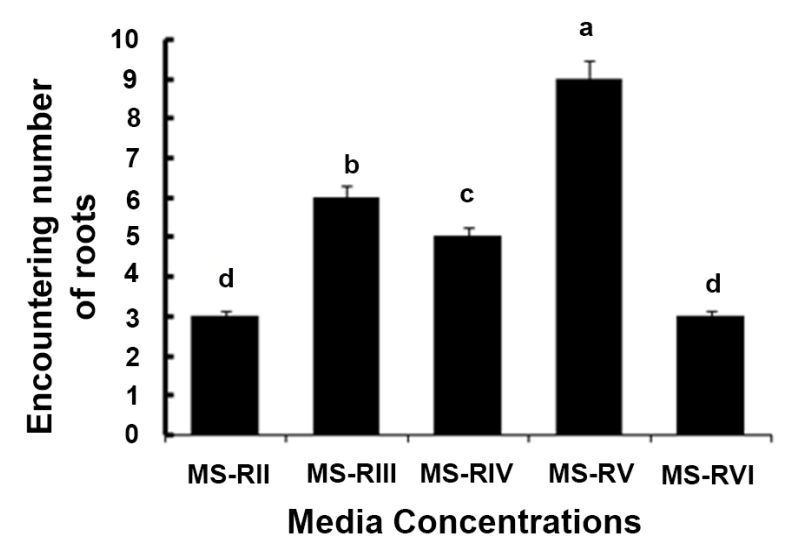

(d)

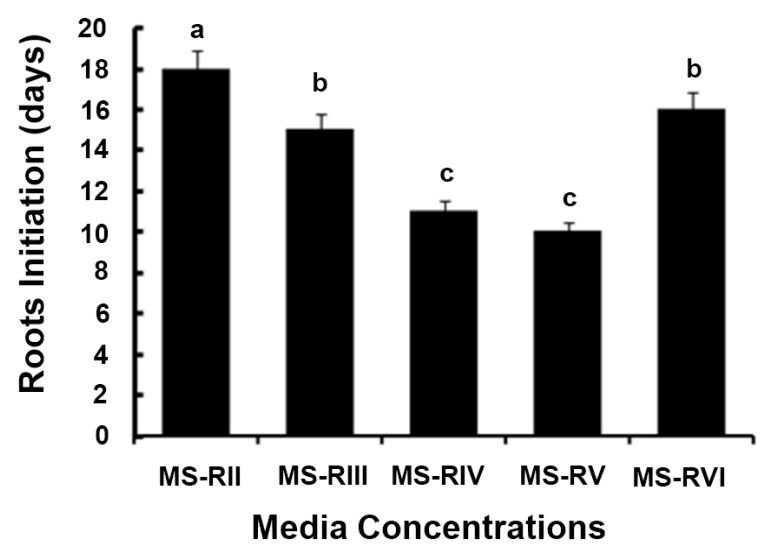

(c)

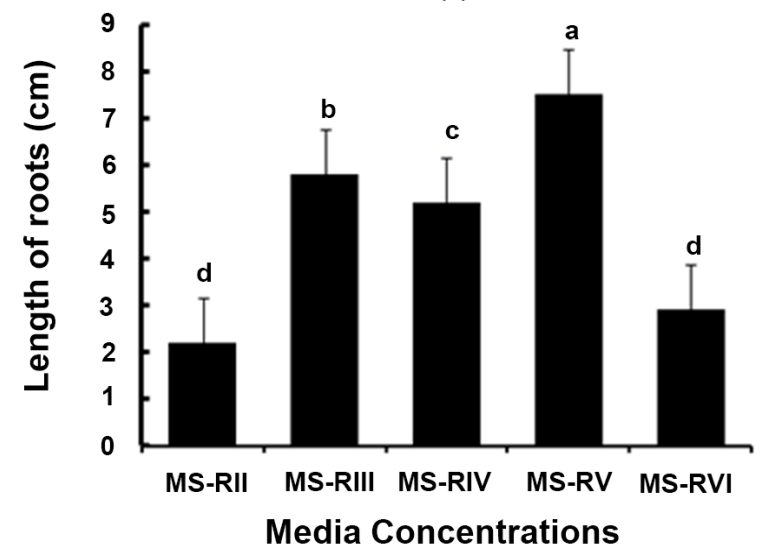

(e)

Figure 4. Proliferation of roots regenerated on different concentrations of growth hormones. Phenotypic observation of regenerated roots of seedlings (a), root proliferation rate (b), root initiations (c), encountering number of roots (d), length of roots (e). a,b means followed by different letter (s) in different columns denotes statistical significant difference regarding analysis of variance. The treatment means were compared using Least Significant Difference (LSD) at 5\% level of Probability. Data are the average of three different biological replications.

shoot of rose regenerated on MS-Basal medium supplemented with different concentrations of NAA are summarized in Figure 4. It was noted that there were no any roots formed on MS-Basal medium (control). Whereas, MS-RII $(2.21 \pm$ $0.15 \mathrm{~cm})$ and MS-RVI $(2.90 \pm 0.15 \mathrm{~cm})$ and/or MS-RIII $(5.80 \pm 0.18 \mathrm{~cm})$ and MS-RIV $(5.22 \pm 0.16 \mathrm{~cm})$ showed more are less similar $(\mathrm{P}>0.05)$ length of roots. However, shoots regenerated on MS-RV medium revealed significantly $(\mathrm{P}<$ 0.05 ) the longer size of root compared to that of shoots cultured on other media. 
It was also observed that there was no any significant difference amongst various replications of the present study.

\subsection{Tissue Culture Proliferated Seedlings and Age-Dependent Leaves of Rose}

Results further concluded that, the longest length of regenerated seedlings was observed at MS-SV and MS-RV media and also possess higher number of leaves (Figures 5(a)-(c)). Although, the leaves were keep more energetic than normal regenerated seedlings. We also had measure the age-dependent leaves of tissue culture regenerated seedlings and normal generated plants, thus we concluded that seedlings and leaves were more totipotent and vigorous in tissue cultured seedlings; thus so far the study still on working processes, further experimentation and results novelty will be assessed upon the completion of project.

\section{Discussion}

In recent years, several studies have examined various components of the culture medium including sucrose, silver nitrate, biotin, thiamine, auxins and salt

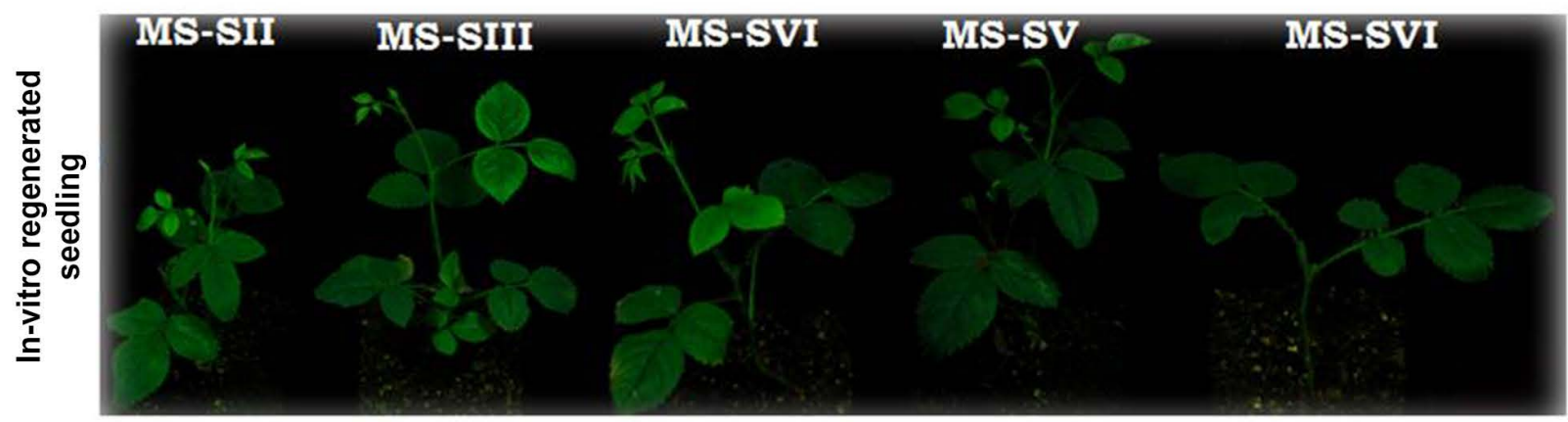

(a)

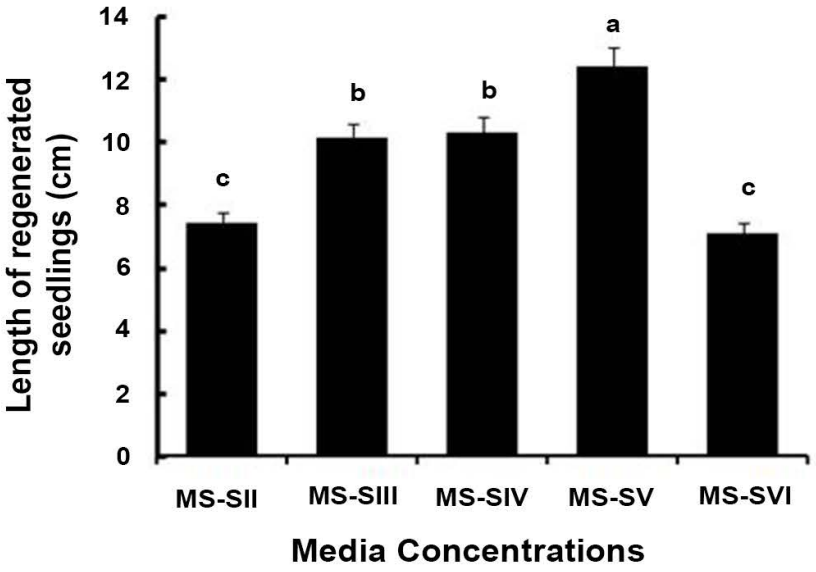

(b)

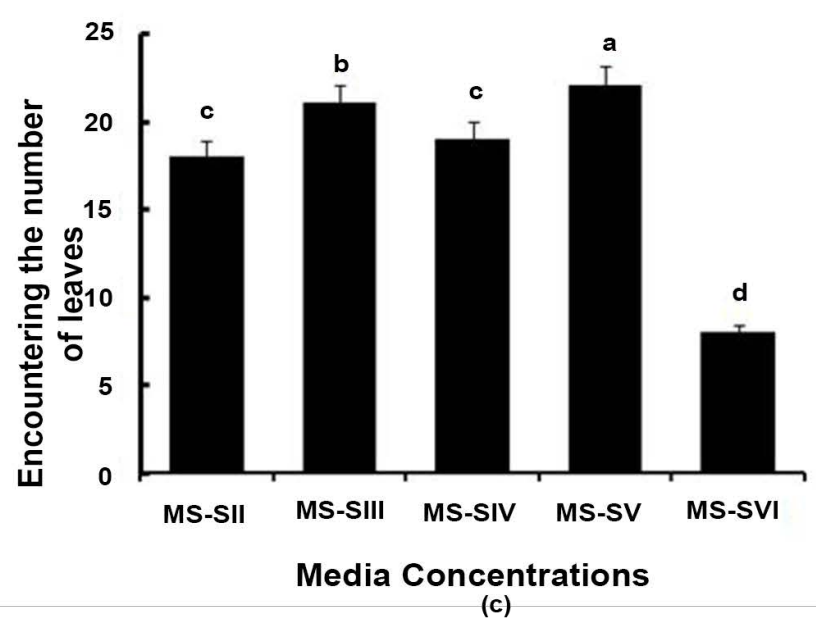

(c)

Figure 5. In vitro Mass-clonal regenerated seedlings of rose .Phenotypic observation of regenerated seedlings (a), length of regenerated seedlings (b), encountering number of leaves (c). ${ }^{\mathrm{a}, \mathrm{b}}$ means followed by different letter (s) in different columns denotesstatistical significant difference regarding analysis of variance. The treatment means were compared using Least Significant Difference (LSD) at 5\% level of Probability. Data are the average of three different biological replications. 
strength and other tissue culture factors. Cell suspension cultures have been employed to study aspects related to physiological aspects. Expected to revolutionize rose propagation, development of system producing mass clonal production is gaining research interest. In addition to offering an effective propagation means, tissue culture proved applicable in genetic improvement of rose through in vitro selection. Tissue culture techniques are useful for rose because of it puts limitation on seed propagation for the production of plant material. On the other hand, the rose usually does not produce seeds for grow and this has apical meristem. It does produce only a few buds early in its life time, thus the number of shoots and consequently, the number of meristems available as source of explants from single stem is usually low. The in vitro regeneration of rose has been successfully used to obtain maximum number of explants in many countries, although improvements in protocols are still being made to overcome some growth and multiplication problems.

\subsection{Growth Hormones Competency Regulate the Shoot Regeneration Potential of Rose}

In present study, It was observed that rose explants cultured on MS medium without addition of hormones (MS-SI) showed significantly $(\mathrm{P}<0.05)$ lower survival rate $(72.50 \%)$ compared to explants on MS medium supplemented with various concentrations of BAP, NAA and GA. Result further reveals that survival rate of explants cultured on MS media supplemented with either MS-SII or MS-SIII each of BAP, NAA and GA was relatively similar $(\mathrm{P}>0.05)$ and were significantly $(\mathrm{P}<0.05)$ optimized $(75.5 \pm 1.18$ or $75.89 \% \pm 0.10 \%$, respectively) than that of cultured on MS medium supplemented with lower concentrations of BAP, NAA and GA (i.e. MS-SI). It is of a interest to note that there were no any significant differences $(\mathrm{P}>0.05)$ found to be amongst the survival rate of rose explants cultured on MS medium supplemented with concentrations of $0.5 \mathrm{mg} / \mathrm{L}, 1.0$ $\mathrm{mg} / \mathrm{L}$ or $2.0 \mathrm{mg} / \mathrm{L}$ each of BAP, NAA and GA i.e. $75.50 \pm 0.28,75.47 \pm 0.18$ and $75.33 \% \pm 0.8 \%$, respectively. Furthermore, compare to that of other medium concentrations, the MS-V medium showed remarkably more better response and showed significantly higher survival rate $(82.4 \pm 1.08)$. These results are fully supported by the findings of Aslam and Khan [10] who reported that with increasing concentrations of BAP and Kinetin also increased the rate of regeneration. Similar effects were also noted in many other plant tissue cultures [11] [12] [13].

\subsection{Proliferation and Multiplication Synchronized at Hormonal Concentrations}

It has been observed that the explants cultured on MS-SI medium has taken more time $(25.0 \pm 0.21$ days) to initiate the shoot (Figure $1(\mathrm{~b}))$. While, on MS-SV medium has taken least time (11.0 \pm 0.15 days). It was further noted that the explants of rose cultured on MS-SII and MS-SIII media have taken downward curve timely response (i.e. $21.28 \pm 0.12$ and $17.45 \pm 0.19$ days). However, the explants cultured on these media have taken significantly less time as com- 
pared to MS-SI medium (25.50 \pm 0.21 days).It was also found that there were no any significant differences $(P>0.05)$ amongst replications of the explants cultured on different media. Similar results have been reported by El-Sharabasy et al. [14] who observed the highest percentage of shoot initiation of Zaghloul and Sewi cultivars from MS supplemented with $4 \mathrm{mg} / \mathrm{L}+2 \mathrm{mg} / \mathrm{L} 2 \mathrm{ip}$ and $3 \mathrm{mg} / \mathrm{L}$ $\mathrm{BAP}+2 \mathrm{mg} / \mathrm{L} 2 \mathrm{ip}$, respectively and both media formed highest shoot/root length. While in another study the authors reported the highest total percentage of shoot formation of Zaghloul and Sewi cultivars from MS-medium supplemented with $4 \mathrm{mg} / \mathrm{L} \mathrm{BAP}+4 \mathrm{mg} / \mathrm{L} 2 \mathrm{ip}$, respectively.

In present study highest numbers of shoots (15.03) were formed in MS-Basal medium supplemented with $4 \mathrm{mg} / \mathrm{L}$ BAP. There was no any regenerated shoot of rose found on MS-Basal medium (control). However, MS-SII, MS-SIII and MS-SIV media showed more or less similar $(\mathrm{P}>0.05)$ number of shoots per explants i.e. $7.03 \pm 0.15,9.02 \pm 0.10$ and 9.02 \pm 0.10 , respectively (Figure $1(\mathrm{c})$ ). While, with increasing concentration of BAP, NAA and GA in MS-Basal medium substantially increased the number of shoots (i.e. $15.03 \pm 0.23$ and $13.03 \pm$ 0.26 , respectively) per explants. These results are inconsistent with reported work of El-Sharbasy et al. [14] who reported the highest number of shoots on MS medium supplemented with $4 \mathrm{mg} / \mathrm{LBAP}$. They also observed the highest number of shoots on MS medium supplemented with $1 \mathrm{mg} / \mathrm{L} 2 \mathrm{ip}$. In another study Aslam and Khan [10] reported the highest frequency of shoot regeneration (85\%) and the number of shoot produced per explants (5.6) on solid MS medium supplemented with 7.4 $\mu \mathrm{M}$ BAP. Additionally, the results for days taken to initiate the roots from the shoot of rose regenerated on MS-basal medium supplemented with different concentrations of NAA was also observed in present study. It was noted that the roots of rose regenerated on MS-RIV medium (11.07 \pm 0.32 ) have taken less time as compared to MS-RIII medium (15.20 \pm 0.19 days). Further, it was interestingly to note that, there was no any root of rose shoot grew on MS-Basal medium (control). However, MS-RII and MS-RIV media showed relatively similar $(\mathrm{P}>0.05)$ number of roots per shoot of rose i.e. $3.05 \pm 0.09$ and $3.02 \pm 0.09$, respectively. Whereas, rose shoots cultured on MS-RV medium exposed the significantly $(\mathrm{P}<0.05)$ highest number of roots amongst the other media. Whereas, MS-RII $(2.21 \pm 0.15 \mathrm{~cm})$ and MS-RVI $(2.90$ $\pm 0.15 \mathrm{~cm})$ and/or MS-RIII $(5.80 \pm 0.18 \mathrm{~cm})$ and MS-RIV $(5.22 \pm 0.16 \mathrm{~cm})$ showed more are less similar $(\mathrm{P}>0.05)$ length of roots. However, shoots regenerated on MS-RV medium revealed significantly $(\mathrm{P}<0.05)$ the longer size of root compared to that of shoots cultured on other media. It was also observed that there was no any significant difference amongst various replications of the present study. These results are similar to the findings of Tabesh et al. [15] and Farahani et al. [16] who reported optimum multiplication rate of shoots on MS medium supplemented with $0.5 \mathrm{mg} / \mathrm{L}$ NAA. While another study conducted by them revealed that the MS-Basel supplemented with $1.0 \mathrm{mg} / \mathrm{L}$ BAP, $1.0 \mathrm{mg} / \mathrm{L} 2 \mathrm{ip}$ and $0.1 \mathrm{mg} / \mathrm{L}$ NAA showed finest results for shoots elongation. 


\section{Conclusion}

Present study concludes that regardless the rose explants cultured on MS-Basal medium (control) was not died; the shoots did not appear up to the end of experiment. While the BAP, NAA and GA at the concentration of $4.0 \mathrm{mg} / \mathrm{L}$ has taken least time to initiate the shoots and furnished significantly higher survival rate with remarkably higher number of shoots. However, the length of shoots was higher at MS-SV medium. Results further concluded that, the longest length of regenerated seedlings and leaves were observed at MS-SV and MS-RV media. We also had measured the age-dependent leaves of tissue culture regenerated seedlings and normal generated plants, thus we concluded that seedlings and leaves were more totipotent and vigorous in tissue cultured seedlings; thus so far the study still on working processes, further experimentation and results novelty will be assessed upon the completion of project.

\section{References}

[1] Kim, E.H and Jules, J. (2009) Rosaceae: Taxonomy, Economic Importance, Genomics. Springer Science + Business Media, LLC., 121.

[2] Evans, A. (2009) Rose Imports. Floraculture International, 42-43.

[3] Hussam, S.M., Khierallah, I. and Saleh, M.B. (2007) Micropropagation of Date Palm (Phoenix dactylifera L.) var. Maktoom through Direct Organogenesis. Proceedings of the 3 rd IC on Date Palm Eds. Acta Hort, 736.

[4] Shah, S.T., Zamir, R., Muhammad, T. and Ali, H. (2006) Mass Propagation of Bougainvillea spectabilis through Shoot Tip Culture. Pakistan Journal of Botany, 38, 953-959.

[5] Kane, M. (2002) Micropropagation and in Vitro Flowering of Rose. In: Trigiano, R. and Gray, D., Eds., Plant Tissue Culture Concepts and Laboratory Exercises, CRC Press, Boca Roton, 119-123.

[6] Carelli, B.P. and Echeverrigaray, S. (2002) An Improved System for the in Vitro Propagation of Rose Cultivars. Scientia Horticulturae, 92, 69-74. https://doi.org/10.1016/S0304-4238(01)00280-1

[7] Sharma, P. and Sarma, K.P. (2014) In Vitro Propagation of Bambusa pallida on Commercial Scale in Assam, India. Journal of Environmental Research and Development, 8, 895-902.

[8] Rajeshbabu, P., Gopalakrishnan, M., Janarthanan, B. and Sekar, T. (2001) An Efficient and Rapid Regeneration Protocol for Micropropagation of Rosa bourboniana from Nodal Explants. International Journal of Current Biotechnology, 2, 24-29.

[9] Murashige, T. and Skoog, F.A. (1962) A Revised Medium for Rapid Growth and Bioassays with Tobacco Tissue Culture. Plant Physiology, 15, 473-479. https://doi.org/10.1111/j.1399-3054.1962.tb08052.x

[10] Aslam, J. and Khan, S.A. (2009) In Vitro Micropropagation of "Khalas" Datepalm (Phoenix dactylifera L.), an Important Fruit Plant. Journal of Fruit and Ornamental Plant Research, 17, 15-27.

[11] Ben, J., Hassairi, H.A., Bigot, C. and Dorion, N. (1998) Adventitious Shoot Production from Strips of Stem in the Dutch Elm Hybrid "Commelin": Plantlet Regeneration and Neomycin Sensitivity. Plant Cell, Tissue and Organ Culture, 53, 153-160.

[12] Biroscikova, M., Spisakova, K., Liptak, S. and Pichler, V. (2004) Micropropagation 
of Mature Wychelm (Ulmusglabra Huds.). Plant Cell Reports, 22, 640-644. https://doi.org/10.1007/s00299-003-0749-8

[13] Junaid, A., Mujib, A., Bhat, M.A., Sharma, M.P. and Samaj, J. (2007) Somatic Embryogenesis and Plant Regeneration in Catharanthus roseus. Biologia Plantarum, 51, 641-646. https://doi.org/10.1007/s10535-007-0136-3

[14] El-Sharabasy, S.F., Bosila, H.A., Ibrahim, A.I., Refay, K.A. and Mohamed, S.M. (2001) Micropropagation Study on Zaghlool and Sewi Cultivars of Phoenix dactylifera L. Plantlet Acclimatization. Proceeding of the 2nd International Conference on Date Palms, El-Ain, 25-27 March 2001, 22-25.

[15] Tabesh, F., Kermani, M.J., Nekouei, M.K., Mousavi, A. and Khalighi, A. (2013) In Vitro Propagation of Damask Rose (Rosa damascene cv. Ispahan). Annals of Biological Research, 4, 134-138.

[16] Farahani, F. and Shaker, S. (2002) Propagation and Growth from Cultured Single Node Explants of Rose (Rosa miniature). African Journal of Plant Science, 6, 277 281. 